\title{
Studies of the in vitro cytotoxic, antioxidant, lipase inhibitory and antimicrobial activities of selected Thai medicinal plants
}

Chutima Kaewpiboon 1,3, Kriengsak Lirdprapamongkol ${ }^{2}$, Chantragan Srisomsap ${ }^{2}$, Pakorn Winayanuwattikun ${ }^{3}$, Tikamporn Yongvanich ${ }^{3}$, Preecha Puwaprisirisan ${ }^{4}$, Jisnuson Svasti ${ }^{2}$ and Wanchai Assavalapsakul ${ }^{5^{*}}$

\begin{abstract}
Background: Traditional folk medicinal plants have recently become popular and are widely used for primary health care. Since Thailand has a great diversity of indigenous (medicinal) plant species, this research investigated 52 traditionally used species of Thai medicinal plants for their in vitro cytotoxic, antioxidant, lipase inhibitory and antimicrobial activities.

Methods: The 55 dried samples, derived from the medicinally used parts of the 52 plant species were sequentially extracted by hexane, dichloromethane, ethanol and water. These 220 extracts were then screened for in vitro (i) cytotoxicity against four cell lines, derived from human lung (A549), breast (MDA-MB-231), cervical (KB3-1) and colon (SW480) cancers, using the MTT cytotoxicity assay; (ii) antioxidant activity, analyzed by measuring the scavenging activity of DPPH radicals; (iii) lipase inhibitory activity, determined from the hydrolytic reaction of $p$-nitrophenyllaurate with pancreatic lipase; and (iv) antimicrobial activity against three Gram-positive and two Gram-negative bacteria species plus one strain of yeast using the disc-diffusion method and determination of the minimum inhibitory concentration by the broth micro-dilution assay.

Results: The crude dichloromethane and/or ethanol extracts from four plant species showed an effective in vitro cytotoxic activity against the human cancer cell lines that was broadly similar to that of the specific chemotherapy drugs (etoposide, doxorubicin, vinblastine and oxaliplatin). In particular, this is the first report of the strong in vitro cytotoxic activity of Bauhinia strychnifolia vines. The tested tissue parts of only six plant species (Allium sativum, Cocoloba uvifera, Dolichandrone spathacea, Lumnitzera littorea, Sonneratia alba and Sonneratia caseolaris) showed promising potential antioxidant activity, whereas lipase inhibitory activity was only found in the ethanol extract from Coscinum fenestratum and this was weak at 17-fold lower than Orlistat, a known lipase inhibitor. The highest antimicrobial activity was observed in the extracts from S. alba and S. caseolaris against Pseudomonas aeruginosa and Candida albicans, respectively.
\end{abstract}

Conclusion: The Thai medicinal plant B. strychnifolia is first reported to exert strong in vitro cytotoxic activities against human cancer cell lines and warrants further enrichment and characterization. The broad spectrum of the biological activities from the studied plant extracts can be applied as the guideline for the selection of Thai medicinal plant species for further pharmacological and phytochemical investigations.

Keywords: Antimicrobial, Antioxidant, Cytotoxic, Lipase inhibitory, Thai medicinal plants

\footnotetext{
* Correspondence: wanchai.a@chula.ac.th

${ }^{5}$ Department of Microbiology, Faculty of Science, Chulalongkorn University,

Phayathai Road, Bangkok 10330, Thailand

Full list of author information is available at the end of the article
} 


\section{Background}

Recent investigations into plants that have been the basis of traditional medicine for a long time have revealed a significant number of novel metabolites with potent pharmacological properties [1-3]. For example, the chemotherapeutic drug, pacitaxel (Taxol) was initially discovered from the bark of the Himalayan Yew tree by screening for anticancer activity in plant extracts [4]. Various types of plants have been used not only for dietary supplements but also as traditional folk treatments for many health problems [5]. Indeed, the long history of folk medicine demonstrates the potential of plants as sources of bioactive compounds [6]. Traditional medicine is widely used throughout Thailand [7], with both ready-made preparations and herbal drugs being used, and a number of these Thai medicinal plants have provided the foundation for modern pharmaceuticals and drug leads [8]. Thailand has a great diversity of indigenous (medicinal) plant species and hence is a potential source for bioactive compounds, including those with potential antitumor [7,9], antioxidant [10,11], anti-lipase (and so potential antiobesity) [9,12] and antimicrobial activities [13,14].

Since current pharmacological reagents are restricted by the increasing spread and evolution of resistance and/or their undesired side effects, and are often difficult to synthesize as the pure bioactive stereoisomer, investigations to explore novel drugs, or those that can act as templates for the development of new therapeutic agents appears imperative. Therefore, the aim of this study was to screen for potential in vitro cytotoxic, antioxidant, lipase inhibitory and antimicrobial activities from the crude extracts of the folk medicinally used parts of 52 species of Thai medicinal plants.

\section{Methods}

\section{Chemicals and reagents}

Ascorbic acid, chloramphenicol, dimethyl sulfoxide (DMSO), doxorubicin, etoposide, $p$-iodonitrotetrazolium violet, $p$-nitrophenyllaurate ( $p$-NPL) vinblastine, oxaliplatin, porcine pancreatic lipase (PPL; Type II: from porcine pancreas), 2,2-diphenyl-1-picryhydrazyl (DPPH) and 3-(4,5-dimethylthiazol-2-yl)-2,5-diphenyltetrazolium bromine (MTT) were purchased from Sigma (USA). Amphotericin B was purchased from Bristol-Myers Squibb (France). Orlistat $\left(\right.$ Xenical $^{\circledR}$ ) was purchased from Roche (Italy). Cell culture media and antibiotics were purchased from Gibco (USA). Fetal bovine serum (FBS) was purchased from Hyclone (USA). All other chemicals were of analytical grade.

\section{Plant materials}

Fifty two types of Thai medicinal plants were selected based on traditional medicinal uses. These plants were grown in Pom Phra Chulachomklao Mangrove Forests, Phra Chulachomklao Fort, Samut Prakarn (Additional file 1: Table S1). The taxonomic identification was done by the members of the Mangrove Forest Restoration and Regeneration Project during 2004 to 2008 from the Metropolitan Electricity Authority, using the available taxonomic key with the aid of the relevant literature (e.g. the ecology of mangrove plants [15] and flora of Thailand). The specimens, collected during August to October 2010, were dried, ground into a fine powder and then extracted as previously described in Mothana et al. [16] with minor modification. Twenty grams of the sample powder was sequentially extracted with hexane, dichloromethane (DCM) and ethanol (300 mL each), respectively, by Soxhlet extraction for $8 \mathrm{~h}$. The residues were dried overnight and then extracted with $300 \mathrm{~mL}$ water in a shaking water-bath at $60^{\circ} \mathrm{C}$ for $8 \mathrm{~h}$. The obtained crude hexane, DCM and ethanol extracts were evaporated to dryness on a rotary evaporator while the crude water extract was freeze dried. The dried samples were then stored at $-20^{\circ} \mathrm{C}$ until use.

\section{In vitro cytotoxic activity assay}

The in vitro cytotoxic activity of the crude extracts was determined from the mitochondrial activity of cell lines which represent the number of viable cells after the treatment, by using the MTT cytotoxic assay as previously described [17] on four different human cell lines in tissue culture. The non-small cell lung adenocarcinoma (A549) and breast cancer (MDA-MB-231) cell lines were purchased from the American Type Culture Collection (Manassas, VA, USA). The cervical (KB3-1) and colon (SW480) cancer cell lines were kindly provided by Professor Gottesman (Laboratory of Cell Biology, National Cancer Institute, National Institute of Health, MD, USA) and Dr. Chanida Vinayanuwattikun (Faculty of Medicine, Chulalongkorn University), respectively.

Cell suspensions in complete medium (CM) (either RPMI (A549 and SW480) or DMEM (MDA-MB-231 and KB3-1), supplemented in both cases with $10 \%(\mathrm{v} / \mathrm{v})$ FBS, 100 units $/ \mathrm{mL}$ penicillin and $100 \mu \mathrm{g} / \mathrm{mL}$ streptomycin), were seeded into each well of a 96 -well plate $\left(5 \times 10^{3}\right.$ cells per well) and incubated at $37^{\circ} \mathrm{C}$ with $5 \%$ (v/v) $\mathrm{CO}_{2}$. After $24 \mathrm{~h}$, the crude extracts at five different concentrations in DMSO (two-fold serial dilutions from 100 to $6.25 \mu \mathrm{g} / \mathrm{mL}$ ) dissolved in the respective CM were then added into the wells and further incubated for $72 \mathrm{~h}$. Thereafter, the media in the wells were removed and replaced with fresh $\mathrm{CM}$ containing $5 \mathrm{mg} / \mathrm{mL} \mathrm{MTT}$ and incubated at $37^{\circ} \mathrm{C}$ for $2 \mathrm{~h}$ to allow the formation of the insoluble formazan crystal by the mitochondrial active (viable) cells. The media were then removed, $100 \mu \mathrm{L}$ DMSO was added to lyse the cell membranes and solubilize the formazan crystals and the absorbance was 
measured at $550 \mathrm{~nm}$ using a Biochrom Asys UVM 340 Microplate Reader (Holliston, MA, USA). The percentage of cell survival was calculated from Eq. (Eq. 1).

$$
\% \text { Cell survival }=\left(\mathrm{OD}_{\mathrm{T}} / \mathrm{OD}_{\mathrm{C}}\right) \times 100
$$

where $\mathrm{OD}_{\mathrm{T}}$ and $\mathrm{OD}_{\mathrm{C}}$ are the mean absorbance of the treated and the control cells, respectively.

The concentration of the extract which caused a half maximal inhibition of cell proliferation $\left(\mathrm{IC}_{50}\right)$, as determined by the MTT assay, was obtained from a semilog plot of the crude extract concentrations against the percentage of cell survival. Etoposide (200-0.39 $\mu \mathrm{g} / \mathrm{mL})$, doxorubicin $(50-0.1 \mu \mathrm{g} / \mathrm{mL})$, vinblastine $(100-0.2 \mu \mathrm{g} / \mathrm{mL})$ and oxaliplatin $(100-0.2 \mu \mathrm{g} / \mathrm{mL})$ were used as the specific positive controls for the A549, MDA-MB-231, KB3-1 and SW480 cell lines, respectively.

\section{DPPH radical scavenging (antioxidant activity) assay}

The DPPH free radical scavenging assay was used for the evaluation of the antioxidant activity of the crude extracts, as previously described [16]. The dried crude hexane, DCM, ethanol and water extracts were each dissolved to five different concentrations in ethanol (10, 50, 100, 500 and $1000 \mu \mathrm{g} / \mathrm{mL})$. The reaction mixture, containing $100 \mu \mathrm{L}$ of the desired extract concentration in ethanol, $25 \mu \mathrm{L}$ of $1 \mathrm{mM} \mathrm{DPPH}$ and $75 \mu \mathrm{L}$ of ethanol were added into a 96-well plate and incubated at $37^{\circ} \mathrm{C}$ for $30 \mathrm{~min}$. The absorbance at $517 \mathrm{~nm}$ was then monitored from the yellowish solution in a Biochrom Asys UVM 340 Microplate Reader. The DPPH radical scavenging activity was then calculated from Eq. (Eq. 2).

$$
\begin{aligned}
& \% \text { of } \mathrm{DPPH} \text { radical scavenging activity } \\
& \quad=\left[\left(\mathrm{A}_{0}-\left(\mathrm{A}_{1}-\mathrm{A}_{2}\right) / \mathrm{A}_{0}\right)\right] \times 100
\end{aligned}
$$

where $A_{0}, A_{1}$ and $A_{2}$ are the absorbance of the DPPH (no crude extract), the crude extract with DPPH and the crude extract without DPPH, respectively.

The concentration which caused a half-maximal reduced DPPH radical level $\left(\mathrm{EC}_{50}\right)$ was then determined. Extracts with an $\mathrm{EC}_{50}<10 \mu \mathrm{g} / \mathrm{mL}$ were considered as having a high level of antioxidant activity [18]. Ascorbic acid $(10,50,100,500$ and $1000 \mu \mathrm{g} / \mathrm{mL})$ was used as a positive control.

\section{Determination of the lipase inhibitory activity}

The lipase inhibitory activity of the crude extracts was estimated from the ability to inhibit the in vitro porcine pancreatic lipase activity as previously described [19] with slight modification. Briefly, the dry crude ethanol and water extracts were dissolved in $50 \mathrm{mM}$ Tris- $\mathrm{HCl}$ $\mathrm{pH} 8.5$ containing $50 \%(\mathrm{v} / \mathrm{v})$ DMSO to a concentration of $50 \mathrm{mg} / \mathrm{mL}$. The assay mixture contained $10 \mu \mathrm{L}$ of one of five different concentrations (two-fold serial dilutions from 2.5 to $0.156 \mathrm{mg} / \mathrm{mL}$ ) of the crude extracts, $12 \mu \mathrm{L}$ of $20 \mathrm{mg} / \mathrm{mL}$ of PPL (type II) in $50 \mathrm{mM}$ Tris- $\mathrm{HCl} \mathrm{pH}$ 8.5 and $10 \mu \mathrm{L}$ of $5.1 \mathrm{mM} p$-NPL in ethanol. The lipase activity was determined from the hydrolysis of $p$-NPL by measuring the absorbance at $410 \mathrm{~nm}$ of the $p$-nitrophenol product formed at $37^{\circ} \mathrm{C}$ for 5 min using a FLUOstar OPTIMA micro reader (BMG LABTECH, Offenburg, Germany). The lipase inhibitory activity was expressed as the percentage of the decrease in $\mathrm{A}_{410}$ when PPL was incubated with the crude extracts compared to the negative control (solvent only), and was calculated from Eq. (Eq. 3).

$$
\% \text { of enzyme inhibition }=[\mathrm{E}-\mathrm{T} / \mathrm{E}] \times 100
$$

where $\mathrm{E}$ and $\mathrm{T}$ are the absorbance of the reaction without and with the crude extract, respectively.

The concentration of the extract which caused a half maximal inhibition of the lipase activity $\left(\mathrm{IC}_{50}\right)$ was obtained from a semilog plot of the crude extract concentrations against the percentage of enzyme inhibition. Orlistat $(250-0.49 \mu \mathrm{g} / \mathrm{mL})$ was used as the positive control.

\section{Antimicrobial assay}

Three Gram-positive (Bacillus subtilis (MCCU0351), Micrococcus luteus (MCCU0350) and Staphylococcus aureus (MCCU0352)) and two Gram-negative (Escherichia coli (MCCU0349) and Pseudomonas aeruginosa (MCCU0359)) bacterial strains, plus the yeast (Candida albicans) were used for the antimicrobial screening.

The antimicrobial activities of the crude ethanol and water extracts were determined using the disc-diffusion and broth micro-dilution assays [16]. For the discdiffusion assay, the various microbes were spread at $1.5 \times 10^{7}$ cells/plate on 9-cm diameter nutrient agar petri dishes. Sterile filter paper discs of $6 \mathrm{~mm}$ in diameter (Whatman, cat. NO. 1442125, lot 577125) were impregnated with $2 \mathrm{mg}$ of the crude extract dissolved in $5 \%(\mathrm{v} / \mathrm{v})$ ethanol, dried and then placed on the surface of the spread agar plates. They were kept for $2 \mathrm{~h}$ in a $4^{\circ} \mathrm{C}$ refrigerator to enable pre-diffusion of the crude extracts and then further incubated at $37^{\circ} \mathrm{C}$ for $18 \mathrm{~h}$, except for $M$. luteus (room temperature for $48 \mathrm{~h}$ ) and C. albicans $\left(30^{\circ} \mathrm{C}\right.$ for $\left.48 \mathrm{~h}\right)$ [20]. At the end of the incubation, the antimicrobial activity was evaluated by measuring the diameter of the inhibition zone. An inhibition zone of $10 \mathrm{~mm}$ in diameter or more was regarded as representing a high antimicrobial activity. Chloramphenicol $(20 \mu \mathrm{g} /$ disc $)$ and amphotericin B $(40 \mu \mathrm{g} /$ disc $)$ were used as positive controls for the bacteria and yeast, respectively.

The crude extracts that revealed a positive antimicrobial activity in the disc-diffusion assay were then evaluated by the broth micro-dilution assay to determine the minimal inhibitory concentration (MIC) against the 
microorganisms as previously reported [16], except with minor modifications. Within sterile 96-well plates, twofold serial dilutions of the selected crude extracts were prepared (in duplicate) in the appropriate broth containing $5 \%(\mathrm{v} / \mathrm{v})$ DMSO to produce a concentration range of 1,000 to $7.8 \mu \mathrm{g} / \mathrm{mL}$. The bacterial cell suspension, at 0.5 McFarland standards (approximately $1.5 \times 10^{8}$ colony forming units $/ \mathrm{mL}$ ) [21] was added into each well, except for the blank wells which served as extract and media sterility controls. Control cultures for bacterial growth without the crude extract were also included in each plate. The plates were then incubated at $37^{\circ} \mathrm{C}$ for $18 \mathrm{~h}$, where after $20 \mu \mathrm{L}$ of a $0.04 \%(\mathrm{w} / \mathrm{v}) p$-iodonitrotetrazolium violet solution was then added to each well and incubated for $30 \mathrm{~min}$. A change in color from yellow to pink, indicating the reduction of the dye from the bacterial growth, was observed. The MIC of the crude extract was determined from the lowest concentration at which no growth of microorganism, as determined by the color change, was observed. Similarly, two-fold dilutions of chloramphenicol (250-7.81 $\mu \mathrm{g} / \mathrm{mL})$ or amphotericin B (500-15.63 $\mu \mathrm{g} / \mathrm{mL})$ were used as a positive control for the bacteria and yeast, respectively.

\section{Results}

Additional file 1: Table S1 lists the ethnobotanical data of the investigated plant species illustrating their botanical names, the part(s) of the plant used for extraction, the traditional folk medicinal uses of these plant tissues, and the yield obtained from each extract (as \% by dry weight of the total dry weight). A total of 220 extracts, representing 52 plant species (since two tissue parts were used for each of Bauhinia strychnifolia, Moringa oleifera and Solanum trilobatum), were screened for in vitro cytotoxic, antioxidant, lipase inhibitory and antimicrobial activities.

\section{In vitro cytotoxic activity}

Of the 52 plant species assayed, the extracts from only four species (B. strychnifolia vines, Coscinium fenestratum stems, Eurycoma longifolia roots and Kalanchoe pinnata leaves) displayed potential in vitro cytotoxicity against the four human cancer cell lines tested (Additional file 1: Table S2).

In terms of the deduced $\mathrm{IC}_{50}$ values, the crude water extracts had only a weak (> $20 \mu \mathrm{g} / \mathrm{mL}$ ) to essentially no activity in all cases, but for the other less polar extracts they varied between the cell lines, plant species and solvents used in the extraction. Nevertheless, typically the crude DCM and ethanol extracts were more active suggesting the bioactive components have a moderate to low polarity.

Overall, the vine extracts from B. strychnifolia were the most effective against three of the four human cancer cell lines. However, it was still effective against the fourth (SW480) cell line. The highest cytotoxic activity $\left(\mathrm{IC}_{50}\right.$ of $\left.0.28 \mu \mathrm{g} / \mathrm{mL}\right)$ was obtained against the MDAMB-231 cell line by the crude hexane extract of B. strychnifolia vines, with the crude DCM extract being strongly cytotoxic against the A549 and KB3-1 cell lines ( $\mathrm{IC}_{50}$ value of 1.16 and $1.86 \mu \mathrm{g} / \mathrm{mL}$, respectively). In fact, this is the first report of the in vitro cytotoxic activity of this interesting plant against human transformed cell lines.

For the remaining three plant species with positive in vitro cytotoxicity, the crude DCM and ethanol extracts of $K$. pinnata leaves showed a better overall in vitro cytotoxicity than the other two plant species, although these $K$. pinnata leaf extracts were not that effective against the A549 cell line. The crude DCM and ethanol extracts from $C$. fenestratum stems were effective against the KB3-1 cell line $\left(\mathrm{IC}_{50}\right.$ values of 3.25 and $2.18 \mu \mathrm{g} / \mathrm{mL}$, respectively). Although the extracts from E. longifolia roots were in general the least effective of the four positive plant species, its DCM and ethanol extracts were strongly cytotoxic against the MDA-MB-231 cell line ( $\mathrm{IC}_{50}$ values of 1.6 and $1.2 \mu \mathrm{g} / \mathrm{mL}$, respectively).

\section{Antioxidant and lipase inhibitory activities}

With respect to the antioxidant activity, an $\mathrm{EC}_{50}$ value of less than $10 \mu \mathrm{g} / \mathrm{mL}$ in the $\mathrm{DPPH}$ radical scavenging assay is generally considered to be effective in this work. However, the positive control of ascorbic acid under these assay conditions was outside this limit $\left(\mathrm{EC}_{50}=12\right.$ $\pm 1.29 \mu \mathrm{g} / \mathrm{mL}$ ). Of the 220 plant extracts, only some of the crude water and ethanol extracts, but not the hexane and DCM extracts, from six plant species (see below) revealed potential DPPH radical scavenging activity. Therefore, it can be speculated that the principal bioactive components are relatively polar compounds and different to those with cytotoxic activities.

Of the 110 crude ethanol and water extracts evaluated from the 52 plant species, extracts from only six plant species were found to have an effective DPPH radical scavenging activity, ranging in the order (lowest to highest $\mathrm{EC}_{50}$ value) of Sonneratia caseolaris leaves, Coccoloba uvifera leaves, Sonneratia alba leaves, Lumnitzera littorea leaves, Allium sativum bulbs and Dolichandrone spathacea leaves $\left(\mathrm{EC}_{50}\right.$ values of $1.92 \pm 0.38,3.08 \pm 1.01$, $3.27 \pm 0.53,4.00 \pm 0.25,4.23 \pm 0.67$ and $5.17 \pm 0.29 \mu \mathrm{g} / \mathrm{mL}$, respectively).

With respect to the crude water extracts, three (S. alba, S. caseolaris and L. littorea) of the six plant species with effective ethanol extracts also had effective $\mathrm{DPPH}$ radical scavenging activity $\left(\mathrm{EC}_{50}\right.$ values of $6.43 \pm 2.29,7.25 \pm 1.52$ and $7.27 \pm 0.64 \mu \mathrm{g} / \mathrm{mL}$, respectively), but no other extracts were effective. Although the water extracts were less effective than the corresponding 
ethanolic ones, it should be born in mind that these are derived from sequential (ethanol before water), potentially non-exhaustive extractions that will vary in their compositions and so it cannot be inferred that they represent different component(s) or specific activities.

With respect to the lipase inhibition, the crude ethanol extract from $C$. fenestratum was the only one found to display effective activity. Nevertheless, this was weak ( $\mathrm{IC}_{50}$ value of $160 \pm 0.02 \mu \mathrm{g} / \mathrm{mL}$ ), compared to that for the positive control of Orlistat $\left(\mathrm{IC}_{50}\right.$ value of $9.25 \pm$ $1.25 \mu \mathrm{g} / \mathrm{mL})$.

\section{Antimicrobial activity}

Using the disc-diffusion assay and taking an inhibition zone of $\geq 10 \mathrm{~mm}$ diameter as the indication of a strong antimicrobial activity [22], from the 110 crude ethanol and water extracts screened from 52 plant species, those from only four plant species were found to exhibit a strong antimicrobial activity (Additional file 1: Table S3). The ethanol extracts of $C$. fenestratum stems showed the broadest range of activity, inhibiting all of the three tested Gram-positive bacteria (S. aureus, B. subtilis and $M$. luteus), and one (E. coli) of the two Gram-negative bacteria as well as the yeast strain (C. albicans). However, the crude ethanol extract from Anacardium occidentale leaves and S. caseolaris leaves were also effective against $E$. coli.

For the aqueous extracts, that from $S$. alba leaves was found to inhibit one ( $M$. luteus) of the three tested Gram-positive bacteria, both tested Gram-negative bacteria (E. coli and P. aeruginosa) and the yeast strain (C. albicans), whilst that from $S$. caseolaris leaves could inhibit E. coli and C. albicans. The extracts from A. occidentale leaves, therefore, appeared to potentially be specific for Gram-negative bacteria.

To obtain the MIC of the crude extracts, the broth micro-dilution assay was utilized to screen those crude water and ethanol extracts that were positive by the disc-diffusion assay. The results (Additional file 1: Table S3) showed that the crude ethanol extract of C. fenestratum stems inhibited the three tested Grampositive and one (E. coli) of the two tested Gram-negative bacteria strains plus $C$. albicans equally and effectively (MIC values of $500 \mu \mathrm{g} / \mathrm{mL}$ ), whilst the only other extract to be active against Gram-positive bacteria (water extract of S. alba on M. luteus) also had a MIC value of $500 \mu \mathrm{g} /$ $\mathrm{mL}$. However, a lower MIC was obtained against the Gram-negative bacteria $P$. aeruginosa and the yeast $C$. albicans from the aqueous extracts of $S$. alba and S. caseolaris $(125 \mu \mathrm{g} / \mathrm{mL})$. These MIC values are typically higher than those for the positive control of chloramphenicol for bacteria (MIC of $\sim 8$ to $32 \mu \mathrm{g} / \mathrm{mL}$, except for $P$. aeruginosa at $125 \mu \mathrm{g} / \mathrm{mL}$ ) but broadly comparable to that for amphotericin B for the yeast (MIC of $250 \mu \mathrm{g} / \mathrm{mL}$ ).
However, these crude extracts are likely to contain many non-bioactive compounds (in mass) and so the actual specific activities after enrichment would potentially be higher.

\section{Discussion}

In vitro cytotoxic activity

According to the United States National Cancer Institute plant screening program, a plant extract is generally considered to have an active cytotoxicity effect if the $\mathrm{IC}_{50}$ value following incubation between 48 to $72 \mathrm{~h}$, is $20 \mu \mathrm{g} / \mathrm{mL}$ or less [23].

The relevant tissue(s) (in terms of the tissue(s) used in folk medicine) from 52 species of medicinal plants in Thailand were screened as their crude hexane, DCM, ethanol and water extracts for in vitro cytotoxic activity against four human transformed (cancer) cell lines. The highest cytotoxic activity was obtained from the crude hexane extract obtained from the vines (but not leaves) of B. strychnifolia against the MDA-MB-231 cell line. Moreover, this extract also had potential strong activity against the KB3-1 cell line, whilst the crude DCM extract exhibited cytotoxic activity against the A549 and KB3-1 cell lines. From the results, the derived $\mathrm{IC}_{50}$ values for the crude hexane and DCM extracts from the vines of B. strychnifolia are not that different on each cell line from the respective positive controls (etoposide, doxorubicin, vinblastine and oxaliplatin). Assuming no strong synergy among all components in the extract, it can be implied that the bioactive component(s) in these fractions could be far more potent than the standard reference drugs and so merits their enrichment and further characterization.

Clinically, B. strychnifolia has been applied for the treatment of human food poisoning diarrhea [24] and also in 2011 as an anti-HIV-1 agent [25]. Nevertheless, the antitumor activity has never been reported. As a consequence, this work appears to be the first report on the antitumor activity of B. strychnifolia.

The crude DCM extract of C. fenestratum showed in vitro cytotoxicity against the KB3-1 cell line, which is consistent with the reported antiproliferative activity against the human colorectal carcinoma (HCT-116) cell line [26], where it apparently induces expression of the peroxisome proliferator-activated receptor $\gamma$ and pro-apoptotic genes.

The crude DCM and ethanol extracts of E. longifolia roots exhibited cytotoxic activity against the MDA-MB231 cancer cell line, which has been reported previously on the human breast cancer cell line MCF-7 where the inhibition was linked to the induction of apoptotic cell death $[27,28]$. In addition, from nearly 65 compounds isolated from the roots of E. longifolia, eight were found to demonstrate strong cytotoxicity towards the human lung cancer (A549) cell line and some of these were also 
strongly cytotoxic against the MCF-7 cell line [29]. Thus, it appears that the crude alcohol extracts from E. longifolia roots may exhibit a preferential or specific cytotoxicity against breast cancer.

The bufadienolide isolated from the methanol extract of $K$. pinnata has been reported to be a potential cancer chemotherapeutic agent since it inhibits the tumor promoting activity of Epstein-Barr Virus [30]. Here, we found that the crude ethanol extract from the leaves of this plant inhibited the growth of the KB3-1 cell line, which was developed from human papilloma virus infected cells. Hence, it is possible that the ethanol extracts affect the regulation of some viral proteins that control cell division.

Overall, the crude hexane and DCM extracts were more active than the corresponding aqueous and ethanol ones, suggesting that the active compound(s) against the cell lines in these plants are of low polarity. In addition, as mentioned before, since these are crude extracts and may contain many non-active components then the $\mathrm{IC}_{50}$ values reported here may in fact be far higher than those of the actual bioactive component(s) in the extracts, assuming no strong synergy between different components. Therefore, these results support that the bioactivityguided enrichment of these fractions is merited.

\section{Antioxidant and lipase inhibitory activity}

With respect to the antioxidant activity, the crude ethanol and water extracts from only six of the 52 investigated plants showed any effective free radical scavenging activity in the DPPH assay when compared to that of the ascorbic acid reference standard. The hexane and DCM extracts did not exert any detectable antioxidant activity in this study. This result is similar to the study on Fenugreek seeds (Trigonella foenum-graecum) which showed that the highest antioxidant activity was found in the ethanol and methanol extracts followed by the aqueous extract with only low activities in the hexane and DCM extracts [31]. Moreover, most of the 52 plants investigated in this study naturally occur (and were obtained from) within mangrove forest areas, which are typically rich sources of phenolic compounds, such as flavonoids [32], to protect the plants from UV radiation $[33,34]$. As a matter of fact, a linear relationship between the flavonoid content and the antioxidant activity has already been reported [35].

With respect to the lipase inhibitory activity, only the crude ethanol and water extracts were evaluated. The low polarity compounds including the natural lipids in the tissue(s) could be extracted by hexane and DCM at sufficiently high concentrations as to interfere in the assay by acting as alternative but unquantified substrates for the lipase providing false positives and potentially masking genuine weak and moderate positives. However, all but one of the 110 water and ethanol extracts were found to be inactive. The exception was the ethanol extract from C. fenestratum stems that exhibited a weak lipase inhibitory activity ( $\mathrm{IC}_{50}$ value of $160 \mu \mathrm{g} / \mathrm{mL}$ ) that had a 17.3 -fold lower $\mathrm{IC}_{50}$ value than that for Orlistat, a known lipase inhibitor. Nevertheless, it is a crude extract, and so the actual $\mathrm{IC}_{50}$ of the active component(s) may be significantly higher. The lipase inhibitory activity from this plant (the first report) gives a suggestion of the potential to screen for novel plant compounds with anti-lipase activity. These may be of clinical dietary use in countering the problems of human obesity. Thus, it may be interesting for further studies to fractionate the crude hexane and DCM extracts to remove the natural lipid content and screen the other fractions for anti-lipase activity.

\section{Antimicrobial activity}

Unfortunately, the crude hexane and DCM extracts, although soluble in DMSO were not soluble in the $5 \%(\mathrm{v} / \mathrm{v})$ DMSO-nutrient broth media used for the broth microdilution assay, where higher DMSO levels are themselves inhibitory in the assay. Therefore, only the 110 crude ethanol and water extracts were screened for antimicrobial activity. Significant antimicrobial activities (inhibition zones $\geq 10 \mathrm{~mm}$ ) were obtained from the extracts of only four plant species, with MIC values of $\leq 500 \mu \mathrm{g} / \mathrm{mL}$ (as determined by subsequent broth assays).

Of the four plants with antimicrobial activity, the crude ethanol extract of $C$. fenestratum stems displayed a broad range of antimicrobial effects against all tested microorganisms except $P$. aeruginosa. Moreover, it has been previously reported to inhibit the growth of Propionibacterium acnes and Staphylococcus epidermidis [36], whereas the methanol extract of this plant was reported to inhibit the growth of $S$. aureus, B. subtilis and E. coli [37].

The aqueous extract from the leaves of $S$. alba displayed an antimicrobial activity against both tested Gram-negative bacteria ( $E$. coli and $P$. aeruginosa), one (M. luteus) of the three tested Gram-positive bacteria (M. luteus), and the yeast $C$. albicans. In agreement with this is that both the methanol and ethyl acetate extracts have been reported to have antimicrobial activity against Gram-positive (Bacillus cereus and S. aureus) and Gram-negative (E. coli) bacteria [38], but the inhibition activity against $P$. aeruginosa and $C$. albicans is newly reported here.

Although the results of this work are consistent with those reported by Tao et al. [39] in that the ethanol extract of $S$. caseolaris had no antimicrobial activity against B. subtilis, S. aureus, $P$. aeruginosa and E. coli, our ethanol extract did inhibit the growth of $E$. coli. In addition, we found that the crude water extract of $S$. caseolaris leaves could inhibit the growth of 
C. albicans, which is consistent with the report that not only the ethanol leaf extract but also the methanol extract of the cork of this plant could inhibit C. albicans [40]. Thus, these two species from the family Sonneratiaceae merit further investigation for antimicrobial agents.

Finally, the ethanol extract from the leaves of $\mathrm{A}$. occidentale demonstrated antimicrobial activity against $E$. coli and $P$. aeruginosa, which is similar to that previously reported [41-43], but is in contrast with the previous report that the ethanol extract of this plant's leaves also inhibited M. luteus, S. aureus and B. subtilis [41,42], which was not observed in the present study.

Overall, the ethanol and aqueous extracts exhibited potential antimicrobial activity and merit further bioactivity guided fractionation to obtain the bioactive component(s). However, since the crude hexane and DCM extracts could not be screened, their initial fractionation and assay for antimicrobial activity may be of value, with further bioactivity guided fractionation as required.

\section{Conclusion}

The in vitro cytotoxic, antioxidant, lipase inhibitory and antimicrobial activities of 52 species of Thai medicinal plants were studied using the tissue source(s) that are used in traditional folk medicine. The crude hexane extract from the vines of $B$. strychnifolia was found to exert a strong in vitro cytotoxic activity against human cancer cell lines and certainly merits further enrichment to isolate the potentially promising bioactive component (s). This work provides the basic data base of selected Thai medicinal plants species that can be used to identify potential novel bioactive compounds for pharmacological and phytochemical investigations. However, the other parts of each plant may not be used in folk medicine for reasons other than a lack of bioactive compound(s), such as digestibility, taste or presence of other deleterious components, and so the other tissues of positive plants should be screened. Regardless, the simple approach of using the knowledge of folk medicine as a first guide to select plants for pharmacological screening appears validated, although it should be extended to include not only the other tissue parts of positive plants, but also close phylogenetic relatives and cultivars.

\section{Additional file}

Additional file 1: Table S1. Ethnobotanical data and percent yield of the investigated Thai plant extracts. S2 In vitro cytotoxic activity of crude extracts against human cancer cell lines. S3 In vitro antimicrobial activity and minimal inhibitory concentrations (MIC) of the investigated crude extracts.

\section{Abbreviations}

CM: Complete media; DCM: Dichloromethane; DMSO: Dimethyl sulfoxide; DPPH: 2,2-diphenyl-1-picryhydrazyl; EC $_{50}$ : Half maximal effective concentration; FBS: Fetal bovine serum; $I_{50}$ : Half maximal inhibitory concentration; MIC: Minimum inhibitory concentration; MTT: 3-(4,5dimethylthiazol-2-yl)-2,5-diphenyltetrazolium bromine; $p$-NPL: paranitrophenyllaurate; PPL: Porcine pancreatic lipase; SD: Standard deviation.

\section{Competing interests}

The authors declare that they have no competing interests.

\section{Authors' contributions}

This is the original work of the authors and the manuscript was not previously submitted to BITE. All authors are aware of, and accept responsibility for, the manuscript. Conceived and designed the experiments: CK, PW, PP, TY, WA. Performed the experiments: CK. Analyzed the data: CK, PW, PP, TY, WA. Contribute reagents, materials, analysis tools: KL, CS, PW, PP, JS, WA. Wrote the paper: CK, PW, TY, WA. All authors read and approved the final manuscript.

\section{Acknowledgements}

The authors would like to thank Dr. Robert Butcher for the proofreading. Anonymous referees whose comments improved the manuscript. Sincere appreciation is extended to the Metropolitan Electricity Authority for identification and provision of the studied plants. Funding is acknowledged from the Office of the Higher Education Commission, Thailand, under the Strategic Scholarships Fellowships Frontier Research Networks (Specific for Southern region) for the Join PhD Program Thai Doctoral degree program; a CHE-SSR-Ph.D. SW Scholarship to CK; the Research Strategic Plan (A1B1) grants RES-A1B1-NS-03 to PW and RES-A1B1-18 to WA; and the Faculty of Science, Chulalongkorn University, Research Fund.

\section{Author details}

${ }^{1}$ Program in Biotechnology, Faculty of Science, Chulalongkorn University, Phayathai Road, Bangkok 10330, Thailand. 'Laboratory of Biochemistry, Chulabhorn Research Institute, Vibhavadee Road, Bangkok 10210, Thailand. ${ }^{3}$ Department of Biochemistry, Faculty of Science, Chulalongkorn University, Phayathai Road, Bangkok 10330, Thailand. ${ }^{4}$ Department of Chemistry, Faculty of Science, Chulalongkorn University, Phayathai Road, Bangkok 10330, Thailand. ${ }^{5}$ Department of Microbiology, Faculty of Science, Chulalongkorn University, Phayathai Road, Bangkok 10330, Thailand.

Received: 20 July 2012 Accepted: 4 November 2012 Published: 13 November 2012

\section{References}

1. Stevigny C, Bailly C, Quetin-Leclercq J: Cytotoxic and antitumor potentialities of aporphinoid alkaloids. Curr Med Chem Anticancer Agents 2005, 5:173-182.

2. Tang J, Feng Y, Tsao S, Wang N, Curtain R, Wang Y: Berberine and Coptidis Rhizoma as novel antineoplastic agents: A review of traditional use and biomedical investigations. J Ethnopharmacol 2009, 126:5-17.

3. Wungsintaweekul B, Umehara K, Miyase T, Noguchi H: Estrogenic and anti-estrogenic compounds from the Thai medicinal plant, Smilax corbularia (Smilacaceae). Phytochemistry 2011, 72:495-502.

4. Nadeem M, Rikhari HC, Kumar A, Palni LMS, Nandi SK: Taxol content in the bark of Himalayan Yew in relation to tree age and sex. Phytochemistry 2002, 60:627-631.

5. Anushia C, Sampathkumar P, Ramkumar L: Antibacterial and antioxidant activities in Cassia auriculata. Glob J Pharmacol 2009, 3:127-130.

6. Temkitthawon P, Viyoch J, Limpeanchob N, Pongamornkul W, Sirikul C, Kumpila A, Suwanborirux K, Ingkaninan K: Screening for phosphodiesterase inhibitory activity of Thai medicinal plants. J Ethanopharmacol 2008, 119:214-217.

7. Siriwatanametanon $\mathrm{N}$, Fiebich $\mathrm{BL}$, Efferth T, Prieto JM, Heinrich M: Traditionally used Thai medicinal plants: In vitro anti-inflammatory, anticancer and antioxidant activities. J Ethanopharmacol 2010, 130:196-207.

8. Farnsworth NR, Bunyapraphatsara N: Thai Medicinal Plant. Bangkok, Thailand: Recommended for primary health care system Prachachon Company; 1992.

9. Kaisoon O, Konczak I, Siriamornpun S: Potential health enhancing properties of edible flowers from Thailand. Food Res Int 2012, 46:563-571.

10. Tachakittirungrod S, Okonogi S, Chowwanapoonpohn S: Study on antioxidant activity of certain plants in Thailand: Mechanism of 
antioxidant action of guava leaf extract. Food Chem 2007, 103:381-388.

11. Wongsa P, Chaiwarit J, Zamaludien A: In vitro screening of phenolic compounds, potential inhibition against a-amylase and a-glucosidase of culinary herbs in Thailand. Food Chem 2012, 131:964-971.

12. Sirinamarattana A, Bavovada R, Pengsuparp T, Pongthananikorn S: Pancreatic lipase inhibitory activity of Thai medicinal plants. J Pharmacol Res 2010, 3:2402-2403.

13. Alzoreky NS, Nakahara K: Antibacterial activity of extracts from some edible plants commonly consumed in Asia. Int J Food Microbiol 2003, 80:223-230

14. Sakunpak A, Panichayupakaranant P: Antibacterial activity of Thai edible plants against gastrointestinal pathogenic bacteria and isolation of a new broad spectrum antibacterial polyisoprenylated benzophenone, chamuangone. Food Chem 2012, 130:826-831.

15. Bunyavejchewin S, Buasalee R: Mangrove Forest: ecology and mangrove plants. Bangkok: Department of national parks, wildlife and plant conservation; 2011.

16. Mothana RA, Lindequist U, Gruenert R, Bednarski PJ: Studies of the in vitro anticancer, antimicrobial and antioxidant potentials of selected Yemeni medicinal plants from the island Soqotra. BMC Complem altern M 2009, 9:7

17. Kanintronkul $Y$, Worayuthakarn $R$, Thasana $N$, Winayanuwattikun $P$, Pattanapanyasat K, Surarit R, Ruchirawat S, Svasti J: Overcoming multidrug resistance in human lung cancer with novel benzo[a]quinolizin-4-ones. Anticancer Res 2011, 31:921-927.

18. Qusti SY, Abo-khatwa AN, Lahwa MAB: Screening of antioxidant activity and phenolic content of selected food items cited in the Holly Quran. J Biol Sci 2010, 2:40-51.

19. Kim HY, Kang MH: Screening of Korean medicinal plants for lipase inhibitory activity. Phytother Res 2005, 19:359-361.

20. Lachumy SJT, Zuraini Z, Sasidharan S: Antimicrobial activity and toxicity of methanol extract of Cassia fistula seeds. Res J Pharm Biol Chem Sci 2010, 1:391-398.

21. Vital PG, Rivera WL: Antimicrobial activity, cytotoxicity, and phytochemical screening of Voacanga globosa (Blanco) Merr. leaf extract (Apocynaceae). Asian Pac J Trop Med 2011, 4:824-828.

22. Londonkar R, Reddy VC, Kumar KA: Potential antibacterial and antifungal activity of Achyranthes aspera L. Rec Res Sci Tech 2011, 3:53-57.

23. Kuete V, Wiench B, Hegazy ME, Mohamed TA, Fankam AG, Shahat AA, Efferth T: Antibacterial activity and cytotoxicity of selected Egyptian medicinal plants. Planta Med 2012, 78:193-199.

24. Chamratpan S, Homchuen S: Ethnobotany in upper northeastern Thailand. Acta Hortic 2005, 675:67-74.

25. Bunluepuech K, Tewtrakul S: Anti-HIV-1 integrase activity of Thai medicinal plants in longevity preparations. Songklanakarin J Sci Technol 2011, 33:693-697.

26. Rojsanga P, Sukhthankar M, Krisanapun C, Gritsanapan W, Lawson DB, Baek SJ: In vitro anti-proliferative activity of alcoholic stem extract of Coscinium fenestratum in human colorectal cancer cells. Exp Thera Med 2010, 1:181-186

27. Tee TT, Azimahtol HL: Induction of apoptosis by Eurycoma longifolia Jack. extracts. Anticancer Res 2005, 25:2205-2213.

28. Tee TT, Cheah YH, Hawariah LP: F16, a fraction from Eurycoma longifolia Jack extract, induces apoptosis via a caspase-9-independent manner in MCF-7 cells. Anticancer Res 2007, 27:3425-3430.

29. Kuo P-C, Damu AG, Lee K-H, Wu T-S: Cytotoxic and antimalarial constituents from the roots of Eurycoma longifolia. Bioorg Med Chem 2004, 12:537-544.

30. Supratman U, Fujita T, Akiyama K, Hayashi H, Murakami A, Sakai H, Koshimizu K, Ohigashi H: Anti-tumor promoting activity of bufadienolides from Kalanchoe pinnata and K. daigremontiana x tubiflora. Biosci Biotechnol Biochem 2001, 65:947-949.

31. Bukhari SB, Bhanger Ml, Memon S: Antioxidative activity of extracts from Fenugreek seeds (Trigonella foenum-graecum). Pak J Anal Chem 2008, 9:78-83.

32. Bandaranayake WM: Traditional and medicinal uses of mangroves. Mangroves and Salt Marshes 1998, 2:133-148.

33. Agati G, Stefano G, Biricolti S, Tattini M: Mesophyll distribution of 'antioxidant' flavonoid glycosides in Ligustrum vulgare leaves under contrasting sunlight irradiance. Ann Bot 2009, 104:853-861.
34. Close DC, McArthur C: Rethinking the role of many plant phenolics: protection from photodamage not herbivores? Oikos 2002, 99:166-172.

35. Ghasemzadeh A, Jaafar HZ, Rahmat A: Identification and concentration of some flavonoid components in Malaysian young ginger (Zingiber officinale Roscoe) varieties by a high performance liquid chromatography method. Molecules 2010, 15:6231-6243.

36. Kumar G, Jayaveera K, Kumar CA, Sanjay UP, Swamy BV, Kumar DK: Antimicrobial effects of Indian medicinal plants against acne-inducing bacteria. Trop J Pharm Res 2007, 6:717-723.

37. Nair GM, Narasimhan S, Shiburaj S, Abraham TK: Antibacterial effects of Coscinium fenestratum. Fitoterapia 2005, 76:585-587.

38. Saad S, Taher M, Susanti D, Qaralleh H, Fadhlina Izyani Bt Awang A: In vitro antimicrobial activity of mangrove plant Sonneratia alba. Asian Pac J Trop Biomed 2012, 2:427-429.

39. Tao W, Xu M, Huang L, Miao S: Antibacterial activity of extracts from four mangrove species in vitro. Med Plant 2012, 3:38-41.

40. Mahadlek J, Phachamud T, Wessapun C: Antimicrobial studies of Sonneratia caseolaris using different agar diffusion method. Res J Pharm Biol Che Sci 2012, 3:404.

41. Arekemase MO, Oyeyiola GP, Aliyu MB: Antibacterial activity of Anacaridum occidentale on some enterotoxin producing bacteria. Int $J$ Biol 2011, 3:92-99.

42. Vijayakumar AD, Kalaichelvan PT: Antioxidant and antimicrobial activity using different extracts of Anacardium occidentale L. Int J ChemTech Res 2011, 2:436-443.

43. Dahake AP, Joshi VD, Joshi AB: Antimicrobial screening of different extract of Anacardium occidentale Linn. leaves. Int J ChemTech Res 2009, $1: 856-858$.

doi:10.1186/1472-6882-12-217

Cite this article as: Kaewpiboon et al:: Studies of the in vitro cytotoxic, antioxidant, lipase inhibitory and antimicrobial activities of selected Thai medicinal plants. BMC Complementary and Alternative Medicine 2012 $12: 217$.

\section{Submit your next manuscript to BioMed Central and take full advantage of:}

- Convenient online submission

- Thorough peer review

- No space constraints or color figure charges

- Immediate publication on acceptance

- Inclusion in PubMed, CAS, Scopus and Google Scholar

- Research which is freely available for redistribution

Submit your manuscript at www.biomedcentral.com/submit
C Biomed Central 